\title{
New records and first births of the Galapagos fur seal, Arctocephalus galapagoensis (Heller, 1904), from the mainland coast of Ecuador
}

\author{
Nuevos casos y primeros nacimientos de lobos finos de Galápagos, \\ Arctocephalus galapagoensis (Heller, 1904), registrados en la costa continental de Ecuador \\ Fernando Félix ${ }^{1}$, Pedro Jiménez ${ }^{1}$, Jéssica Falconí ${ }^{1}$ and Oscar Echeverry ${ }^{2}$ \\ ${ }^{1}$ Fundación Ecuatoriana para el Estudio de Mamíferos Marinos FEMM. P.O. Box 09-01-11905, Guayaquil, Ecuador \\ ${ }^{2}$ Corporación Ecuatoriana de Investigación y Servicios Educativos, CEISE. Quito, Ecuador \\ fernandofelix@femm.org
}

Resumen.- El lobo fino de Galápagos (Arctocephalus galapagoensis) ha sido registrado recurrentemente en la costa continental de Ecuador, especialmente durante eventos El Niño. Algunos de estos animales sobrevivieron varios meses, tanto en cautiverio como silvestres, lo que sugiere una habituación parcial a las condiciones locales. En este trabajo presentamos cinco nuevos casos, incluyendo dos hembras que tuvieron cría, constituyéndose en los primeros casos registrados de nacimientos de esta especie fuera de Galápagos. Su presencia en la costa continental de Ecuador sería motivada por condiciones oceánicas cálidas y de baja disponibilidad de alimento en Galápagos a causa de El Niño 2004-2005.

Palabras clave: Arctocephalus galapagoensis, Ecuador, El Niño, alumbramientos, distribución

\section{Introduction}

The Galápagos fur seal Arctocephalus galapagoensis is endemic to the Galápagos Islands and is distributed mainly on islands with rocky shores adjacent to intense upwelling areas, particularly those located on the northwest side of the archipelago (Reeves et al. 1992, Salazar 2002). This species is the smallest of the eared Pinnipedia, with less sexual dimorphism than other otariids, and is well adapted to equatorial climatic conditions (Repenning et al. 1971, Trillmich 1984, Reeves et al. 1992). Its presence outside the archipelago is known only from a few dozen records of vagrant individuals that arrived to the coasts of South and Central America. Félix et al. (2001) reported 10 individuals from the continental coast of Ecuador during the past decade, indicating that the frequency of occurrence increased during El Niño years. Galapagos fur seals have also been recorded in the south of Colombia, with a similar occurrence pattern as in Ecuador (Capella et al. 2002). Two other individuals of this species were recorded even further north, in southwest Mexico, during the 1997-98 El Niño (Aureoles-Gamboa et al. 2004).
All the animals recorded previously from continental Ecuador and Mexico, as well as eight of ten cases recorded from Colombia, were of single animals and did not involve pups, but in several cases young animals. The presence of Galapagos fur seals outside the archipelago has been explained, either by changes in the environmental conditions during El Niño events or wandering behavior (Félix et al. 2001, Capella et al. 2002). Low prey availability would be a major ecological force driving such large-distance movements.

In this note we report five new records of the Galapagos fur seal from mainland Ecuador (Fig. 1), including two adult females that gave birth, thus constituting the first breeding for this species outside the archipelago. In all five cases the individuals were identified by their external appearance, i.e. hair coloration, short muzzle, body size and digits of the rear flippers of similar length (Townsend 1934, Repenning et al. 1971, Reeves et al. 1992). 


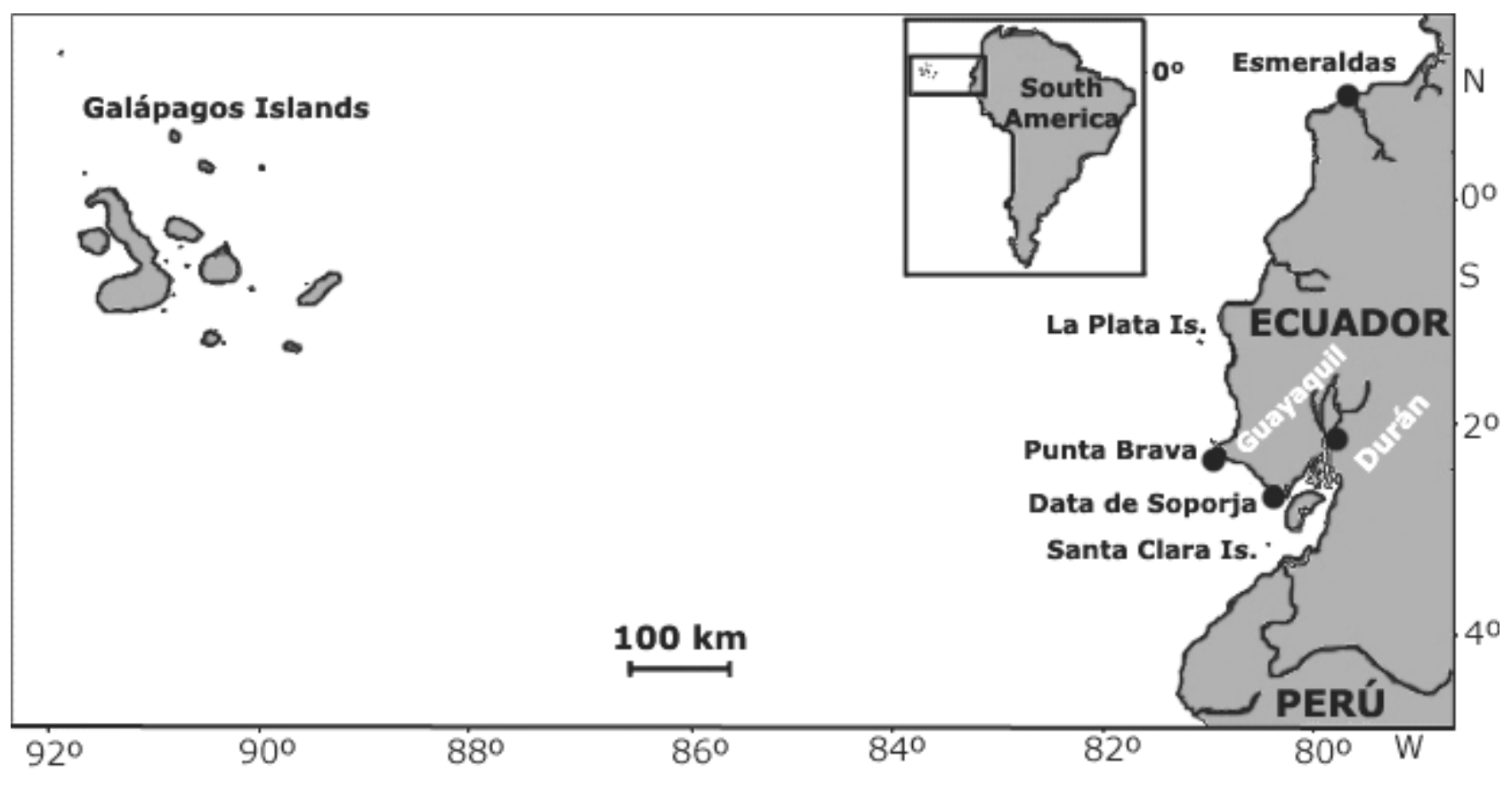

Figure 1

Sites (small circles) on the mainland coast of Ecuador where records of Galapagos fur seal were documented between 2004 and 2005. On the left side of the figure is the Galapagos archipelago, $1,000 \mathrm{~km}$ west of the mainland

Sitios (círculos pequeños) en la costa continental de Ecuador donde registros del lobo fino de Galápagos fueron documentados entre 2004 y 2005. A la izquierda de la figura está el archipiélago de Galápagos, localizado a 1000km al oeste del continente

\section{The records}

\section{Birth at Esmeraldas}

On 1 September 2004, the presence of a sea lion at Esmeraldas $\left(00^{\circ} 59^{\prime} \mathrm{N}, 79^{\circ} 40^{\prime} \mathrm{W}\right)$ drew the attention of the port authority personnel. The next morning, they realized that the animal was an adult female that had given birth during the night, since a newborn pup was also present. This was reported to the Charles Darwin Station in Galapagos, and then to the Fundación Ecuatoriana para el Estudio de Mamíferos Marinos (FEMM) in Guayaquil. We could not obtain more information because this happened $400 \mathrm{~km}$ north from FEMM base in Guayaquil, but photographs of the animals were available for species identification (Fig. 2a). A few days after the animals' arrival, someone picked up the pup, probably while the mother left presumably for feeding. On 7 September, the dead pup was brought to an aquarium in Atacames, $30 \mathrm{~km}$ south of Esmeraldas; skin samples of the dead seal were preserved in alcohol and given to one of us (OE).

\section{Birth at Data de Posorja}

A second birth occurred on 31 October 2005 at Data de Posorja $\left(01^{\circ} 42^{\prime} \mathrm{S}, 80^{\circ} 18^{\prime} \mathrm{W}\right)$. Just like in the Esmeraldas case, a solitary fur seal arrived at the coast next to the pier of this village. On the following morning evidently the same animal was seen 200-300 m south, where the beach has a rocky projection, and it was accompanied by a newborn pup. The animals were examined and photographed for the first time on 2 November, when they were resting between rocks on the lower part of the beach (Fig. 2b). The mother's length was estimated to be between 1.1 and $1.2 \mathrm{~m}$. The umbilical cord and part of the placenta were still hanging from the pup's 

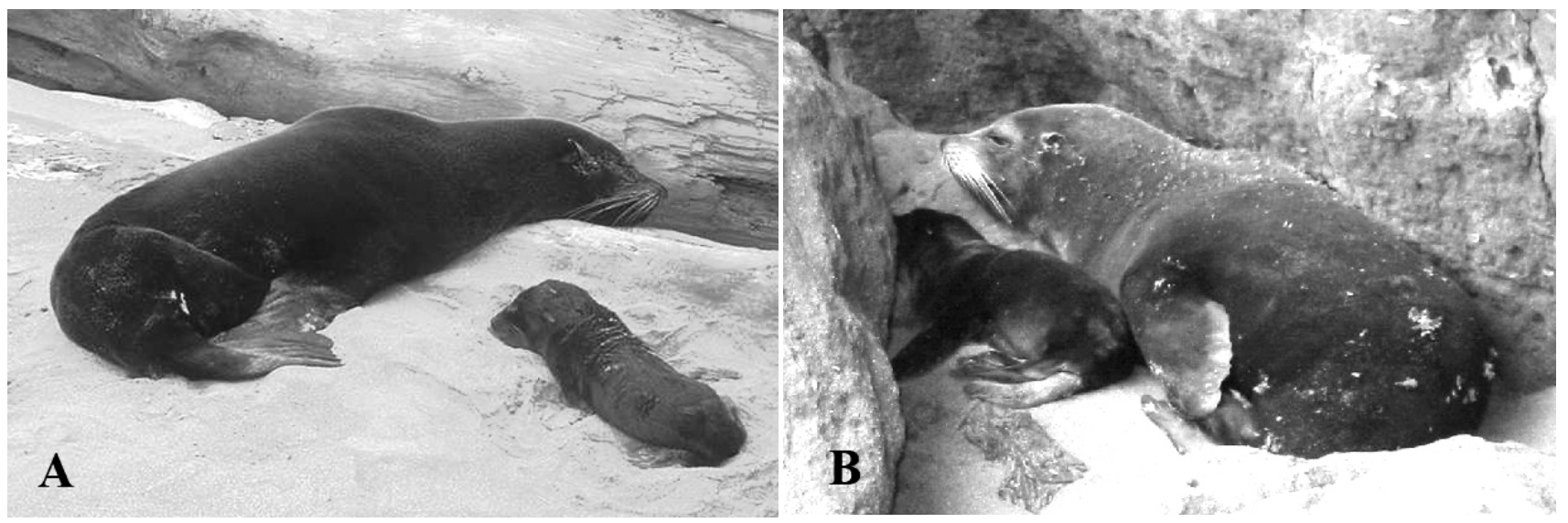

Figure 2

Mother and pup Galapagos fur seals recorded in Esmeraldas (left) (Photo: Hugo Ricaurte) and Data de Posorja (right). Note in right photograph remains of the placenta below the pup's rear flippers

Madre y cachorro del lobo fino de Galápagos registrados en Esmeraldas (izquierda) (Foto cortesía de Hugo Ricaurte) y en Data de Posorja (derecha). Nótese en este último caso restos de la placenta debajo de las patas posteriores del cachorro

belly. During the first three days the mother stayed almost constantly with the pup and made only brief sorties into the water, presumably for feeding. On one occasion the mother was observed pushing the pup into the water, where they spent a few minutes swimming together. The mother and pup moved up and down the beach face following the tidal cycles. During low tide, they spent time between rocks in a shaded part of the beach, but when the tide rose they had to move to a more exposed zone over rocks on the higher part of the beach. The pup was frequently seen suckling. However, on the fourth day after the birth the mother went to sea and was not observed to return. The pup was able to climb over and behind a 50-60 cm high rock, where it spent time during the low tide, and it was also able to walk alone when the tide rose. On a couple of occasions, we attempted to force-feed the pup with commercially available cow's milk, but it refused and vomited what it was given. The pup stayed on the beach under observation for six more days and then died, evidently of starvation. The ten-day old, recently dead pup measured $51 \mathrm{~cm}$ in length from the tip of snout to the tip of tail and weighted $5 \frac{1}{4} \mathrm{lb}(2.3 \mathrm{~kg})$, and a skin sample was collected for future studies.

\section{Other records}

Three other cases of Galapagos fur seals were recorded from mainland Ecuador during 2005 (Fig. 3). A young individual of unknown sex was recorded for the first time on 28 May, and an adult male, on 20 June at Punta Brava, Salinas $\left(02^{\circ} 11^{\prime} \mathrm{S}, 79.58^{\prime} \mathrm{W}\right)$, where they were photographed. Both animals were found on the seaward margin of a rocky area next to a sandy beach, around $100 \mathrm{~m}$ from another rock outcrop which supports a small colony of the South American sea lion Otaria flavescens (see Félix 2002). Both fur seals looked healthy and were frequently observed resting or swimming nearby. Remarkably, they were never seen together and even maintained some 20-30 m apart when resting, always on the same rock. Both animals stayed at the site at least until 2 July.

The third case in 2005 was a young male, found on 15 May at Duran ( $\left.2^{\circ} 10^{\prime} \mathrm{S}, 79^{\circ} 50^{\prime} \mathrm{W}\right), 100 \mathrm{~km}$ up the Guayas River. It is unknown how this individual arrived so far upstream, but it is not the first case of an individual of this species being found so far up-river (see Félix et al. 2001). The animal was captured by the environment police and taken to Parque Histórico, an 

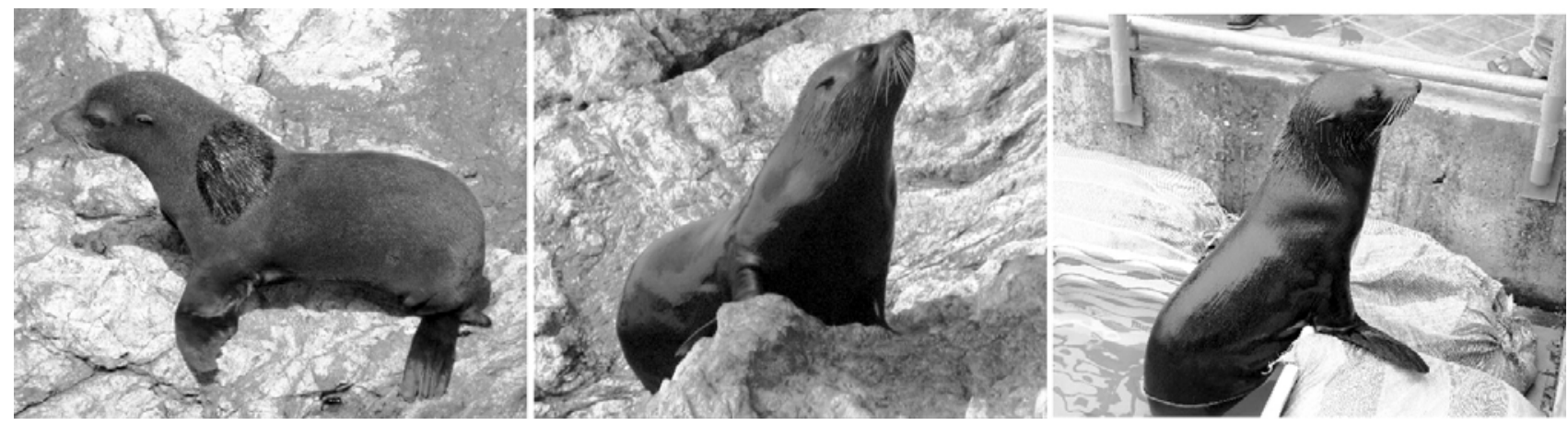

Figure 3

Three additional cases of Galapagos fur seals found on mainland Ecuador in 2005. The sub-adult in the left photograph and the adult male in the center were found at Punta Brava, Salinas. The young male in the right photograph was found at Duran

Tres casos adicionales de lobos finos de Galápagos encontrados en la costa continental de Ecuador en 2005. El subadulto de la fotografía izquierda así como el macho adulto del centro fueron encontrados en Punta Brava, Salinas. El joven macho de la fotografía derecha fue encontrado en Durán

animal rescue facility a few kilometers away from the capture site. When it arrived at the facility the animal was $110 \mathrm{~cm}$ in length and weighed $35 \mathrm{~kg}$ (77 lb). It was maintained in quarantine under veterinarian care and fed with frozen fish (tilapia). Forty days later, the seal was released at La Plata Island off the central coast of Ecuador $\left(01^{\circ} 15^{\prime} \mathrm{S}, 81^{\circ} 05^{\prime} \mathrm{W}\right)$.

\section{Discussion}

Over the past 15 years the occurrence of Galapagos fur seals on the mainland coast of Ecuador has been rare but, during or immediately after El Nino events, it has been common up to five individuals to be reported over a relatively short period of time (Chiluiza et al. 1998, Félix et al. 2001). However, the presence of new born pups had not been previously recorded. The presence of the two mothers and pups, as well as the other three animals recorded during the first half of 2005, was probably related to the 2004-2005 El Niño. In November 2004, after a persistent thermal anomaly of $+1^{\circ} \mathrm{C}$ in the Central and Western Equatorial Pacific that began in June 2004, oceanographic conditions in the Southeast Pacific showed a slight anomaly of surface temperature of $+0.5^{\circ} \mathrm{C}$. Although this characterized this El Niño event as slight, the Galapagos Islands and the mainland coasts of Ecuador and Peru were affected (Comisión Permanente del Pacífico Sur 2005). These unusually warm oceanic conditions are thought to have resulted in reduced availability of usual prey items for seals in Galapagos.

According to Trillmich \& Limberger (1985), this species is highly vulnerable to drastic environmental changes such as those caused by an El Niño. This was shown during the intense oceanographic changes that occurred during the 1982-83 El Niño, when almost all individuals from the four youngest year classes, $30 \%$ of the adult population, and almost all of the territorial males disappeared from the study area at Fernandina Island. Trillmich \& Limberger (1985) argued that these missing animals had all died. However, the impact of El Niño on the population dynamics of this species seems even more complex. The recurrent reports of Galapagos fur seals on the coasts of the South American mainland (Félix et al. 2001, Capella et al. 2002) as well as Mexico (Aureoles-Gamboa et al. 2004) show that some animals emigrated from Galapagos, arriving more than 2,000 km away from their native area. It is hypothesized that these large distance displacements during El Niño events were in response to low prey availability in Galapagos, and the animals were forced to explore alternative feeding strategies in order to survive. Sea lions, possibly Galapagos fur seals, have been also observed in the Azuero Peninsula, Panama $\left(7^{\circ} 25^{\prime} \mathrm{N}, 8^{\circ} 15^{\prime} \mathrm{W}\right)$ (D. 
Arauz $^{1}$, pers. comm.); we postulate that these animals had left their normal foraging grounds and displaced in search of better feeding conditions in the seasonal upwelling of the Panama Bight. The fact that this area rich in productivity extends in a south-southwest direction toward the Galapagos archipelago, and is most productive during the first part of the year (D’Croz et al. 1991, Rodríguez et al. 2003) when oceanographic conditions are least favorable in the Galapagos due to the warm season, supports the suggestion that seals in Panama were Galapagos fur seals. Nonetheless, even if Galapagos fur seals are able to successfully reach the mainland coasts, it is not known if these animals eventually returned to their breeding colonies in the archipelago, and were able to reproduce. If not, no matter how successful there long distance displacements may have been, they would be insignificant to population maintenance, and demographically would be the same as dead.

The occurrence of Galapagos fur seals on distant mainland coasts during non-El Niño years is more difficult to explain. Since this population has decreased by $80 \%$ during the past 25 years, from 30,000-40,000 animals at the end of 70's to 6,000-8,000 in 2001 (Salazar 2002), it is unlikely that their presence in continental waters is due to dispersion (emigration). Some individuals, both in captivity and in the wild, seem to have adapted - at least temporarily - to the conditions on the continent (see also Félix et al. 2001 and Capella et al. 2002, for additional examples), and it cannot be ruled out that some of them have remained in mainland waters following an El Niño event, or possibly seals in continental waters were born from mothers that arrived from Galapagos. Similar cases of births, such as those reported here, could occur at other mainland Ecuadorian sites with better conditions, and it could be possible for the pups to survive. At Data de Posorja, a fishermen informed the first author that he had seen several small sea lions in caves at Santa Clara Island, in the outer part of the Gulf of Guayaquil (0310'S, 80²7'W). This was corroborated by other fishermen who regularly visit Santa Clara Island (B. Haase $^{2}$, pers. comm.). Although anecdotal, this information suggests that other sites, still unknown, could provide adequate shelter to this species. In this light it is relevant to point out that there are other two

${ }^{1}$ Diana Arauz is the Regional Technical Coordinator of the Plan of Action for the South Pacific-CPPS at Guayaquil, Ecuador.

2 Ben Haase is the director of the Whale Museum (FEMM), Salinas, Ecuador. species of otarids colonizing new areas on the coast of Ecuador during the last few decades. South American sea lions established a non-reproductive colony at Salinas $\left(02^{\circ} 10^{\prime} \mathrm{S}, 81^{\circ} \mathrm{W}\right)$ after the 1997-98 El Niño (Félix 2002), which continues to exist at the time of writing. Similarly, the presence of a few individuals of the Galapagos sea lion (Zalophus wollebaeki) at $\mathrm{La}$ Plata Island ( $\left.1^{\circ} 15^{\prime} \mathrm{S}, 81^{\circ} 05^{\prime} \mathrm{W}\right)$ - $20 \mathrm{~km}$ west mainland Ecuador - has been documented for decades (Nowak 1986, Palacios et al. 1997).

The dates of the two births that occurred on mainland Ecuador coincided with the breeding period of this species in Galapagos: from August through November (Trillmich 1984, Salazar 2002). In Galapagos, pregnant mothers usually arrive at the coast one or two days before they give birth to a single pup, which usually weigh $3-4.5 \mathrm{~kg}$, and the mothers stay near the pup continually for one week before leaving to feed (Trillmich 1984). The weight of the pup born at Data de Posorja showed that it was underweight and evidently dehydrated; the mother could have been undernourished during pregnancy because of a scarcity of food and/or the long journey from Galapagos. The Galapagos fur seal feeds on squid and small schooling fish such anchovies, mackerels and lantern fish mainly by night in surface waters of around $30 \mathrm{~m}$ in depth (Clarke \& Trillmich 1980, Kooyman \& Trillmich 1986, Dellinger \& Trillmich 1999). Although these species are also available along the coast of Ecuador, they could be more scattered, deeper or further offshore than required by a pregnant seal.

It is not clear if the new born pub at Data de Posorja was abandoned by the mother or if she died at sea. However, it is not rare for mothers of this species in Galapagos to abandon their pups, a liability from the high energetic investment and time that maternal care involves in this species (Trillmich 1984). Starvation was the main cause of infant mortality in Galapagos sea lion colonies during 1982-83 El Niño, as a consequence of reduced prey availability for this species (Trillmich \& Limberger 1985). At Data de Posorja stresses on the female were exacerbated by the tourists and local visitors who disturbed the animals, especially by touching and holding the pup when the mother was away. There was at least one attempt to take the pup, and the seals were also threatened by dogs. These additional sources of stress interfered with nursing and may have led the mother to leave her pup. 


\section{Acknowledgments}

The authors wish to thank Eva Danulat from the Charles Darwin Station who informed us about the event in Esmeraldas and sent photographs taken by Commander Hugo Ricaurte. Raúl Sánchez reported the presence of the individual at Data de Posorja to FEMM. Ruth and Kléber Paladines collaborated with the FEMM team during our visits to Data de Posorja. Mireya Pozo of the Forestry District (Ministry of the Environment) and Yara Pesantes of Parque Histórico allowed us to examine the Duran specimen. Jack Frazier, Ben Haase and two anonymous reviewers made valuable suggestions on improving this manuscript.

\section{Literature cited}

Aureoles-Gamboa D, Y Schramm \& S Mesnick. 2004. Galápagos fur seals, Arctocephalus galapagoensis, in México. Latin American Journal of Aquatic Mammals 3(1): 77-80.

Capella JJ, L Flórez, P Falk \& D Palacios. 2002. Regular appearance of otariid pinnipeds along the Colombian Pacific coast. Aquatic Mammals 28(1): 67-72.

Chiluiza D, W Aguirre, F Félix \& B Haase. 1998. Varamientos de mamíferos marinos en la costa continental ecuatoriana, período 1987-1995. Acta Oceanográfica del Pacífico, INOCAR, Ecuador 9(1): 209217.

Clarke MR \& F Trillmich. 1980. Cephalopods in the diet of fur seals of the Galapagos Islands. Journal of Zoology, London 190(2): 211-215.

Comisión Permanente del Pacífico Sur. 2005. Informe técnico regional sobre las condiciones oceanográficas, meteorológicas y biológico-pesqueros del Pacífico Sudeste (2003-2004). Guayaquil, Ecuador. 124 pp.

D’Croz L, JB del Rosario \& JA Gómez. 1991. Upwelling and phytoplankton in the Bay of Panama. 1991. Revista de Biología Tropical 39(2): 233-241.

Dellinger T \& F Trillmich. 1999. Fish prey of the sympatric Galapagos fur seals and sea lions: seasonal variation and niche separation. Canadian Journal of Zoology 77: 12041216.
Félix F. 2002. Una colonia de lobos marinos sudamericanos (Otaria flavescens) en Salinas, Ecuador. Acta Oceanográfica del Pacífico, INOCAR, Ecuador 11(1): 327-331.

Félix F, G Lento, J Davis, B Haase \& D Chiluiza. 2001. El lobo fino de Galápagos Arctocephalus galapagoensis en la costa continental de Ecuador, primeros registros confirmados a través de análisis morfológicos y genéticos. Estudios Oceanológicos 20: 63-68.

Kooyman GL \& F Trillmich. 1986. Diving behavior of Galapagos fur seals. IEn: Gentry, RL \& GL Kooman (eds), Fur seals: maternal strategies on land and at sea, pp. 186-195. Princeton Univ. Press. USA.

Nowak B. 1986. Isla de la Plata and the Galápagos. Noticias de Galápagos 48, p. 17.

Palacios DM, F Félix, L Florez-González, JJ Capella, D Chiluiza \& B Haase. 1997. Sightings of Galapagos sea lions (Zalophus californianus wollebaeki) on the coasts of Colombia and Ecuador. Mammalia 61(1):14-116.

Reeves RR, BS Stewart \& S Leatherwood. 1992. The Sierra Club Handbook of Seals and Sirenians. 359 pp. Sierra Club Books. San Francisco. USA.

Repenning CA, SR Peterson \& CL Hubbs. 1971. Contributions to the systematics of the southern fur seals, with particular reference to the Juan Fernandez and Guadalupe species. Antarctic Research Series 18: 1-34.

Rodrígues-Rubio E, W Schneider \& R Abarca. 2003. On the seasonal circulation within the Panama Bight derived from satellite observations of wind, altimetry and sea surface temperature. Geophysical Research Letters 38(7): 1410, doi:10.1029/2002GL016794, 2003.

Salazar S. 2002. Lobo marino y lobo peletero. In: Danulat, E \& GJ Edgar (eds). Reserva Marina de Galápagos, Línea de Base de la Biodiversidad, pp. 267-290. Fundación Charles Darwin / Servicio del Parque Nacional Galápagos, Santa Cruz, Galápagos, Ecuador.

Townsend CH. 1934. The fur seal of the Galapagos Islands. Zoologica 18(2): 43-56.

Trillmich F \& D Limberger. 1985. Drastic effects of El Niño on Galapagos pinnipeds. Oecologia 67: 19-22.

Trillmich F. 1984. Natural History of the Galapagos fur seal (Arctocephalus galapagoensis, Heller). In: R Perry (ed). Key Environments-Galapagos, pp. 215-223. Pergamon Press, Oxford, England. 